\title{
Phytoremediation of a Lead Contaminated Soil: Assisted Approach by EDTA and Native Bacteria
}

\author{
Elisabetta Franchi ${ }^{1}$, Roberto Bagatin ${ }^{1}$, Francesca Pedron ${ }^{2}$, Irene Rosellini ${ }^{2}$, Meri Barbafieri ${ }^{2}$, \\ Gianniantonio Petruzzelli ${ }^{2}$ \\ ${ }^{1} 1$ Eni S.p.A, Renewable Energy \& Environmental Laboratories \\ S. Donato Milanese (MI), Italy \\ elisabetta.franchi@eni.com \\ ${ }^{2}$ Institute of Ecosystem Study, National Council of Research \\ Pisa, Italy \\ francesca.pedron@ise.cnr.it; irene.rosellini@ise.cnr.it; meri.barbafieri@ise.cnr.it; gianniantonio.petruzzelli@ise.cnr.it
}

\section{Extended Abstract}

Phytoextraction represents an ecological and cost-effective way to remove non-biodegradable pollutants, such as heavy metals, from contaminated soils and thus, stands for one of the most attractive in situ plant-based technology.

Lead $(\mathrm{Pb})$ is one of the most common metal pollutants in soil. It is usually concentrated in surface layers of soil with only a slight portion of the total metal found in solution. To increase bioavailability and therefore, the uptake and translocation of metals into plants, the addition of chelating agents has been extensively used in phytoextraction, and some organic acids are particularly effective in increasing metals solubility (1).

The aim of this work was the study of a phytoextraction strategy to remove lead from the soil of a former oil terminal, located in Italy. Micro- and mesocosms trials with the contaminated soil and the species Brassica Juncea and Helianthus annuus (sunflower) were performed. The treatment with the mobilizing additive EDTA positively affected the absorption of $\mathrm{Pb}$ by the plants, proving to be very effective under the adopted experimental conditions. After the EDTA addition, the concentrations of $\mathrm{Pb}$ in the aerial part of brassica and sunflower have doubled, by increasing (mean values) from 27 to 50 $\mathrm{mg} \mathrm{kg}-1$ and from 25 to $46 \mathrm{mg} \mathrm{kg}-1$ respectively. The effect of EDTA at the root apparatus was slightly different in the two species: in brassica, the lead levels raised from 93 to $135 \mathrm{mg} \mathrm{kg}-1$ while in sunflower from 85 to $207 \mathrm{mg} \mathrm{kg}-1$. Anyhow, in both species, higher uptake was detected at roots with respect to shoots.

Fifteen lead resistance bacteria were isolated and selected from this contaminated soil. Genomic DNA from the pure culture of the isolates was subjected to 16 rRNA gene sequencing, leading to identify bacteria belonging to Bacillus, Arthrobacter and Ochrobactrum genera. These selected microbial strains were then subjected to a further characterization including the possible resistance to other heavy metals and the presence of plant growth promoting properties such as the production of auxins (3-indol-acetic acid: IAA), ammonia, siderophores, exopolysaccharides, the formation of biofilm (in vitro pellicle), the nitrogen fixation capacity and the inorganic phosphate solubilization ability (2). A microbial consortium prepared with the ten strains (Plant Growth Promoting Bacteria: PGPB) showing the best in vitro attractive features was used to inoculate microcosms of brassica and sunflower. The results pointed out that the addition of the inoculum increased the biomass production (30\% for brassica and $16 \%$ for sunflower) thus significantly contributing to the rise of the total uptake of lead.

\section{References}

[1] S. Doumett, L. Lamperi, L. Checchini, E. Azzarello, S. Mugnai, S. Mancuso, G. Petruzzelli, M. Del Bubba, "Heavy metal distribution between contaminated soil and Paulownia tomentosa,in a pilot-scale assisted phytoremediation study: influence of different complexing agents," Chemosphere, vol. 72, pp. 1481-1490, 2008.

[2] E. Franchi, E. Rolli, R. Marasco, G. Agazzi, S. Borin, P. Cosmina, I. Rosellini, M. Barbafieri, G. Petruzzelli, "Phytoremediation of a multi contaminated soil: mercury and arsenic phytoextraction assisted by mobilizing agent 
and plant growth promoting bacteria," Journal of Soils and Sediments, 1-13. DOI: 10.1007/s11368-015-1346-5, 2016. 